\title{
THE EFFECT OF DISCOVERY LEARNING MODEL TOWARD STUDENT HIGHER ORDER THINKING SKILLS IN DYNAMIC ELECTRICITY SUBJECT MATTER AT SMA RAKSANA MEDAN ACADEMIC YEAR 2014/2015
}

\author{
Kristin Natalia Tondang dan Sahyar \\ Jurusan Fisika FMIPA Universitas Negeri Medan \\ Jalan Willem Iskandar Pasar V Medan, Sumatera Utara \\ christine_natalie30@yahoo.com
}

\begin{abstract}
Study aimed to analyze the effect of discovery learning model toward student's higher order thinking skill. The type of this research was quasi experimental, with experiment class used discovery learning and control class used conventional learning. The population was all of the tenth class of SMA Raksana Medan academic year 2014/1015 which consist of seven classes. Sample was taken with a simple random sampling technique. The data in higher order thinking skill was collected by essay tests. Data analyzed with $t$ test. The result of the study showed that there was positive effect of discovery learning model toward student's higher order thinking skill in experiment class or given by discovery model. It proved from posttest result in experiment class was higher than control class or there was significant difference of post test score, although in higher order thinking level, both of class still in less level, but student who given discovery learning had higher value than control class.
\end{abstract}

\section{Keyword : Conventional Learning; Discovery Learning Model; Higher Order} Thinking Skill

\section{INTRODUCTION}

In performing activities of daily life, people cannot be separated from the process of thinking hence to survive in the ever-changing circumstances, uncertain, and the competitive, they must have the ability to acquire, select, and process information. This capability requires critical thinking, systematic, logical, and creative and has a willingness to cooperate effective that can be obtained from the learning process in schools.

Therefore, in the learning process, students should be trained in

the skills of thinking, especially higher order thinking skill. Higher order thinking skills are very important to be integrated in any subjects, including physics lessons in high school.

Higher order thinking skills (High Order Thinking Skills - HOTS) is a thought process that is not just memorize and pass back information known. It is the ability to connect, manipulate, and transform knowledge and experience already possessed to think critically and creatively in an effort to determine the decisions and solve problems in new situations. Means the use of 
higher order thinking skills must think more than just remembering, understanding and applying the formula. In a process of learning physics if student use higher order thinking skill, the learning will be a meaningful learning.

According to one of the International Study on students' cognitive abilities are TIMSS (Trends in Mathematics and Science Study) conducted by the IEA (International Association for the Evaluation of Educational Achievement).TIMSS 2011 results in the field of physics shows Indonesia gained 397 value, this value is below the international average is 500. The data indicates that the absorption of learners in learning in physics education. Based on the results of TIMSS, it can be said that the students' ability to think critically Indonesia is still low

To overcome this problem, we need model student-centered. One model that can be used is a discovery learning model. Jerome Bruner in Arends believe that discovery learning is a model of teaching that emphasized the importance of helping students understand the structure or key ideas of a discipline, the need for active student involvement in the learning process, and a belief that true learning comes through personal discovery (2012;402). Discovery learning is a type of learning where learners construct reviews their own knowledge by experimenting with a domain, and inferring rules from the results of reviews these experiments. Because of reviews these constructive activities, it is assumed they will understand the domain at a higher level than when the necessary information is just presented by a teacher or an expository learning environment (Joolingen.1999).

\section{THEORETICAL}

Discovery learning in Arends's book is a model of teaching that emphasized the importance of helping students understand the structure or key ideas of a discipline, the need for active student involvement in the learning process, and a belief that true learning comes through personal discovery (2012;402). Hosnan (2014: 281) believes this model emphasizes the importance of understanding the structure or important ideas to a discipline, through the active involvement of students in the learning process. Different to Conventional learning that is focused in one direction. It is a learning that can be used by the teacher during the learning process in the classroom. This learning model is dynamic, meaning that the learning model is consistent with that used by schools and teachers in the school.

Based on Lefrancois (1997; 206) the constructivist approach to teaching is based on the assumption that students should build (construct) knowledge for themselves. Hence, constructivist approaches are basically discovery oriented.

There are four playing features of the discovery models based on Majoribanks (1991:79-80) First is predisposition of the learners, the cultural experiences in children's backgrounds needed to Encourage children to learn and to want to learn. Second is the structure and form of knowledge to be presented to the learner, including its mode of representation. Third is the sequence of interaction from enactive through iconic to symbolic representation. Fourth is the form and pacing of reinforcement.

If all the playing features of the discovery models do by teacher, 
higher order thinking of student will increase. King et al. assumed that higher order thinking skills include critical, logical, reflective, metacognitive, and creative thinking. They are activated when individuals encounter unfamiliar problems, uncertainties, questions, or dilemmas. Thinking Skills are the mental processes we use to do things like: solve problems, make decisions, ask questions, make plans, pass judgment, organize information and create new ideas.

The results of the learning process called learning outcomes

Learning outcomes achieved by students is closely related to the formulation of teacher instructional objectives planned in advance. Horward Kingsley divided three kinds of learning outcomes, namely (a) the skills and habits, (b) knowledge and understanding, (c) attitudes and ideals. Five categories of learning outcomes, namely (a) the informal verbal, (b) intellectual skills, (c) cognitive strategies, (d) attitude, and (e) motor skills.

The original Taxonomy in Krathwohl (2002) developed a carefully-provided definition for the call now of the six major categories in the cognitive domain. Categorize are Knowledge, Comprehension, Application, Analysis, Synthesis, and Evaluation.

Thinking Skills are the mental processes we use to do things like: solve problems, make decisions, ask questions, make plans, pass judgement, organise information and create new ideas. Often we're not aware of our thinking - it happens automatically - but if we take time to ponder what's going on then we can become more efficient and more creative with our minds.
Thinking skills resist the precise forms of definition we have come to associate with the setting of the specified objectives for schooling. Nevertheless, it is relatively easy to list some key features of higher order thinking. When we do this, we become aware that, although we cannot define it exactly, we can recognize higher order thinking when it occurs.

\section{RESEARCH METHOD}

Type of research is a quasi experiment. To know, the model is affected or not to the student higher order thinking. The population of this research were all students in Science10th grade in SMA Raksana Medan, that consist of 7 classes with the students average is about 40 students. Experiment class is X-3 and Control class X-6.

The sample in this research is two classes will be taken by cluster random sampling. One class as experiment class that used discovery learning model is $\mathrm{X}-3$ and the other class as control class used conventional learning is $\mathrm{X}-6$.

This research conducted in experimental design and divided into two groups, experimental group which is applying discovery learning model and control group which is applying conventional learning. Pretest and post-test are administered to both experimental group and control group before and after treatment. The design of research can be shown in Table 1.

Table 1. Design Of Research

\begin{tabular}{|c|c|c|c|}
\hline Group & $\begin{array}{c}\text { Pre } \\
\text { Test }\end{array}$ & Treatment & $\begin{array}{c}\text { Post } \\
\text { Test }\end{array}$ \\
\hline $\mathrm{E}$ & $\mathrm{T}_{1}$ & $\mathrm{X}$ & $\mathrm{T}_{2}$ \\
\hline $\mathrm{C}$ & $\mathrm{T}_{1}$ & $\mathrm{O}$ & $\mathrm{T}_{2}$ \\
\hline
\end{tabular}


Note: $\mathrm{E}=$ Experimental group

$\mathrm{C}=$ Control group

$\mathrm{T}_{1}=$ Pretest for experiment class and control class

$\mathrm{T}_{2}=$ Post - test for experiment class and control class

$\mathrm{X}=$ Applying discovery learning model

$\mathrm{O}=$ Applying conventional learning

The instrument used is objective test (pre-test and post-test). The evaluation test arranged based on the topics as much as five questions in essay form. The data that will be analyzed from the test results are the content validity. Data processed by using statistical techniques include tests normality, homogeneity test and test hypothesis

\section{RESULT AND DISCUSSION}

This research is a quasi experiment involving two classes are given different learning models that experimental class taught by a model of Discovery Learning, and the control class was taught with Conventional Learning. Therefore, before class applied treatment, it was given a pre-test to determine students' prior knowledge. 
Table 2. Average value, Standard Deviation, Variance

\begin{tabular}{|c|l|c|c|c|}
\hline No. & \multicolumn{1}{|c|}{ Data } & Average value & Standard Deviation & Variance \\
\hline 1. & Pretest experiment class & 4.2 & 3.63 & 13.17 \\
2. & Pretest control class & 5.6 & 3.49 & 12.19 \\
3. & Post test experiment class & 44.3 & 23.91 & 572.11 \\
4. & Post test control class & 37.56 & 19.93 & 397.20 \\
\hline \multicolumn{2}{|c|}{1.58.} & all the data conclude
\end{tabular}

Table shown pre test class in experimental is 4.2 and pre test in control class is 5.6. Post test in experimental class is 44.3 and post test in control class is 37.56 the result shown both of classes have different ability. Experimental class has higher score than control class. There is no significant difference both of them with range value 6.74. Data result will continue to analysis test by normality test, homogeneity test, and hypothesis test.

Data normality test pretest and posttest experimental class and control class using test Liliefors. Provided that the value of pretest and posttest both of groupis normal or $\mathrm{L}_{\text {count }}<\mathrm{L}$ table with a 0.05 and $\mathrm{N}=40, \mathrm{~L}_{\text {table }} 0.1410$. Pre test experiment class $\mathbf{L}_{\text {count }} 0.1308$, pre test control class $\mathrm{L}_{\text {count }} 0.1224$, Post test experiment class $\mathrm{L}_{\text {count }} 0.1281$, Post test control class $\mathbf{L}_{\text {count }} 0.1392$, all data is normal.

Pre test experiment class and Pre test control class have variance 13.17 and 12.19 with $\mathbf{F}$ count 1.22, $\mathbf{F}$ table 1.58. Post test experimental class and Post test control class have variance 572.11 and 397.20 with $\mathbf{F}$ count $1.39, \mathbf{F}$ table

homogeneity.

Pre test experimental class is 4.2 and pre test control class is 5.6. $t_{\text {count }}$ of both data is 1.08 and $\mathrm{t}$ table is 1.994 . It can be concluded that the initial ability of students in experiment class same as the initial ability of students in control class. Because of that $\mathrm{H}_{0}$ is accepted. Initial ability both of class is same. It can be continued to $t$ test one tale to test is model has effect or not to student's ability by post test data that has been collected.

From the above data, it can be seen that the average value posttest in the experimental class is higher than the average value in the control class. With the range scale 12.63 and $t_{\text {count }}>t$ table $(2.59>$ 1.667), it can be concluded that there is effect of Discovery Learning Model in Dynamic Electricity topic in class X SMA Raksana Medan. Ha is accepted, it means Higher Order Thinking Skill in Experiment Class higher than Control Class. There was positive effect of Discovery Learning Model to student higher order thinking skill. 
Scores of higher order descriptors that appear at the time thinking skills of each student is to solve problems of higher order the number of scores obtained in thinking skills tests. It can be seen accordance with the number of in table 3 below.

Table 3. Data Pre Test and Post Test of Experiment and Control Class

\begin{tabular}{|l|c|c|}
\hline \multicolumn{1}{|c|}{ Class } & Pre test & Post test \\
\hline Experiment Class & 4.2 & 44.3 \\
\hline Control Class & 5.6 & 37.56 \\
\hline \multicolumn{2}{|c|}{ test every class can be seen in } \\
The level of higher order $\quad$ figure 1 below
\end{tabular}

thinking skill in pre test and post

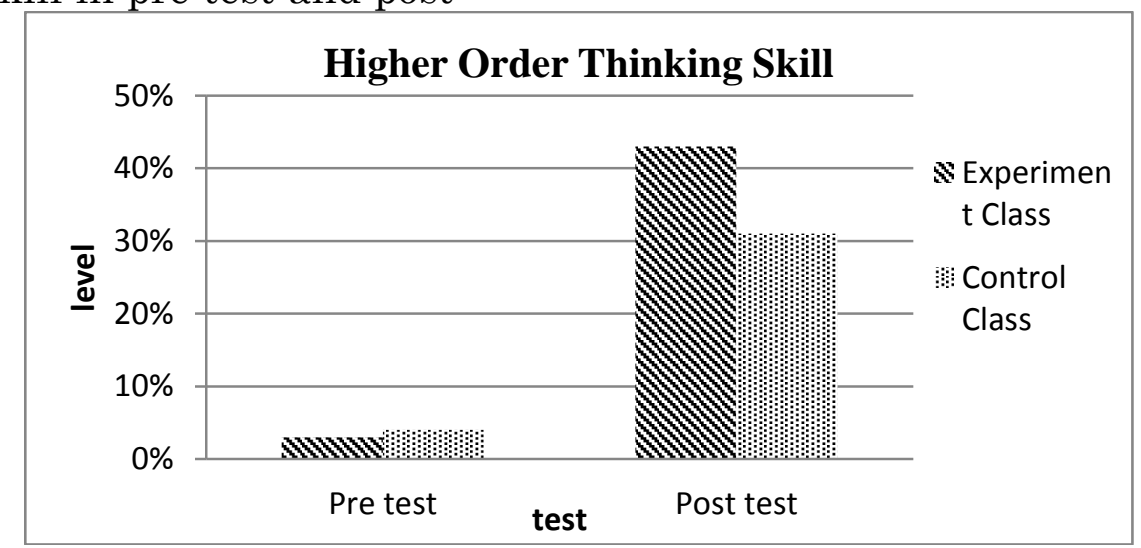

Figure 1. Diagram of Student's Higher Order Thinking Skill 
Data pretest and post test change into percentage and diagram show, pre test in experimental class and control class just reach $3 \%$ and $4 \%$. It's really less, and after student give treatment, data post test change into percentage and student in experimental class reach about $43 \%$ and control class about $31 \%$. Student who studied by discovery learning has higher level than control class.

Why there is no significant difference of research maybe it because students in experimental class and control class don't have ability to think critically that higher order thinking sill needs. In teaching process in experimental class student much confused to do what teacher explain, do experiment, and answer worksheet. They difficult to answer worksheet and exercise that need high thinking process. They don't habit to answer divergent question. While, the ability of student higher order thinking skill of students increased, although it didn't reached a satisfactory ability or student ability still in less level, but it appears that the discovery model had positively to student thinking skills. It be in accordance on Bell in Kementrian Pendidikan dan Kebudayaan (2013), discovery learning is learning that occurs as a result of the students manipulate, create structure, and transforming information so that finding new information

This can be seen from the percentage increase in the ability of experiment class students achieve $39 \%$ defeat the ability of students who use conventional learning $26 \%$.

Learning by using Discovery Model provides advantages to the students who have lower ability and students who have higher ability because they can work together in completing academic tasks. Student with high ability can help friends, and lower ability students can receive knowledge or information from the higher ability students.

This research was same with Yurahly et al. (2014) used discovery learning in SMA $\mathrm{N} 4$ Palu,. the results showed that the average value of the experimental class students higher than the control class. The reserach from Putrayasa et al. (2014) shown that students who studied by discovery learning was higher than control class. Balim (2009) obtained data that the students of class VII of the Public Elementary School in Turkey that used discovery learning had average value 71.17 while students who used conventional models had average value of 67.03. Yang et al. (2010) conducted a study in Taiwan's elementary education obtain data that the class that studied by discovery model had average value 57.63 while the class who studied conventional learning is 46.41. Based on four researches before and this research result, discovery learning model has positive effect to student higher order thinking skill.

However, in this study there were still weaknesses found in research, ie students is less prepared for presenting results of the discussion when the teacher calls the group, resulting in the exposure of the results of the discussion groups is less effective, it is because students are still afraid to present the results of the discussions, and also models is less effective for students who do not have the willingness to learn because in this model, students are actively to looking for information a lesson. 


\section{CONCLUSION}

Higher Order Thinking Skill student who given Discovery Learning Model on Dynamic Electricity Topic in $\mathrm{X}$ grade at SMA Raksana Medan Semester II A.Y. 2014/2015 have initial ability 4.2 and after student given treatment, there is $41.1 \%$ increased level of thinking processes to be 44.3 Higher Order Thinking Skill student who given Conventional Learning that only have $31.96 \%$ and initial ability 5.6 increased to 37.56 . There is positive effect of Discovery Learning Model to Student's Higher Order Thinking Skill because the value of post test in experimental class is higher than control class, that is 44.3 and 37.56 with $t_{\text {count }}>t_{\text {table }}=$ $2.59>1,667$ with $\alpha=0,05$, therefore, the both value is not significant.

\section{REFFERENCES}

Arends, R., (2012), Learning to Teach Ninth Edition, McGraw-Hill Company Inc, New York.

Balim, A.G.,(2009), The Effect of Discovery Learning on Students Success and Inquiry Learning Skill, Egitim Arastirmalari-Eurasian Journal of Educational Research, Vol. 35,1-20. (Retrieved Frebruary 2015)

Hosnan, M., (2014), Pendekatan Saintifik dan Kontekstual Dalam Pembelajaran Abad 21, Ghalia Indonesia, Bogor.

Joolingen, V.W., (1999), Cognitive Tools for Discovery Learning, International Journal of Artificial Intelligence in Education, Vol. 10, 385397.(Retrieved December 2014)

Krathwohl, D. R, (2002), Theory into Practice (Volume 41), Ohio,
College of Education The Ohio

State University.

Kementrian Pendidikan dan

Kebudayaan, (2013), Model

Pembelajaran Penemuan,

Kementrian Pendidikan dan

Kebudayaan, Jakarta.

Lefrancois, G. R., (1997), Psychology

for Teacher (9th ed),

Wadsworth, Belmont, CA.

Majoribanks, K., (1991), The

Foundation of Students

Learning, Pergamon Press,

Australia.

Putrayasa, I.M., H, Syahruddin., \& I

Gede, M., (2014), Pengaruh

Model Pembelajaran Discovery

Learning dan Minat Belajar Terhadap Hasil Belajar IPA Siswa. Jurnal Mimbar PGSD Universitas Pendidikan

Ganesha, Vol. 2, No. 1, 1-11. (Retrieved January 2015)

Resnick, L.B., (1987), Education and Learning to Think, National Academy Press, Washington DC.

Yang, E., Calvin, L., Emily, C., Tina, C.,\& Tak Wai, C,. (2010), The Effectiveness of Inductive Discovery Learning in $1: 1$ Mathematics Classroom, Graduate Institute of Network Learning Technology, National Central University, Taiwan, (1) 743-747. (Retrieved January 2015)

Yurahly, D., I Wayan, D., \& Darsikin., (2014), Model Pembelajaran Guided Discovery dan Direct Instruction Berbasis Keterampilan Proses Sains Siswa SMA Negeri 4 Palu, Jurnal Pendidikan Fisika Tadulako, Vol. 2 No. 2ISSN 23 383 240. (Retrieved January 2015 
Jurnal Inpafi

Vol. 4, No. 1, Februari 2016 